\title{
Development of a word accentuation test for predicting cognitive performance in Portuguese-speaking populations
}

\author{
Desenvolvimento de um teste de acentuação de palavras em português para predição de \\ desempenho cognitivo \\ Gislaine GIL1', Regina Miksian MAGALDI', Alexandre Leopold BUSSE1, Elyse Soares RIBEIRO',2, Sonia Maria \\ Dozzi BRUCKI'3 , Mônica Sanches YASSUDA ${ }^{3,4}$, Wilson JACOB-FILHO', Daniel APOLINARIO'
}

\begin{abstract}
The Word Accentuation Test (WAT) has been used to predict premorbid intelligence and cognitive performance in Spanish-speaking populations. It requires participants to read a list of words without the accent marks that indicate the stressed syllable. Objective: As Portuguese pronunciation is also strongly based on accent marks, our aim was to develop a Brazilian version of the WAT. Methods: An initial pool of 60 items was constructed and a final version of 40 items (named WAT-Br) was derived by item response theory. A sample of 206 older adults underwent the WAT-Br and a standardized neuropsychological battery. Independent ratings were performed by two observers in 58 random participants. Results: The items showed moderate to high discrimination ( $\alpha$ between 0.93 and 25.04) and spanned a wide range of difficulty ( $\beta$ between -2.07 and 1.40). The WAT-Br was shown to have an excellent internal consistency (Kuder-Richardson Formula $20=0.95$ ) and inter-rater reliability (intraclass correlation coefficient $=0.92$ ). It accounted for $61 \%$ of the variance in global cognitive performance. Conclusion: A version of the WAT for Portuguese-speaking populations was developed and proved to be a valuable tool for estimating cognitive performance.
\end{abstract}

Keywords: Neuropsychological tests, intelligence, elderly.

\section{RESUMO}

O Teste de Acentuação de Palavras (TAP) tem sido utilizado para predizer inteligência pré-mórbida e desempenho cognitivo em populações de língua espanhola. Requer que os sujeitos leiam uma lista de palavras sem os sinais gráficos de acentuação que indicam a sílaba tônica. Objetivo: Como a pronúncia da língua portuguesa também é fortemente baseada em acentos gráficos, nosso objetivo foi desenvolver uma versão brasileira do TAP. Métodos: Um conjunto inicial de 60 itens foi construído e uma versão final de 40 itens (denominada TAP-Br) foi derivada por teoria da resposta ao item. Uma amostra de 206 idosos foi submetida ao TAP-Br e a uma bateria neuropsicológica padronizada. Registros de pontuação independentes foram realizados por dois observadores em uma subamostra de 58 participantes aleatórios. Resultados: Os itens apresentaram moderada a alta discriminação ( $\alpha$ entre 0,93 e 25,04) e abrangeram uma ampla gama de dificuldades ( $\beta$ entre -2,07 e 1,40). O TAP-Br apresentou excelente consistência interna (Fórmula de Kuder-Richardson 20 = 0,95) e confiabilidade inter-examinador (Coeficiente de Correlação Intraclasse = 0,92). O escore do TAP-Br explicou 61\% da variância do desempenho cognitivo global. Conclusão: Uma versão do TAP para as populações de língua portuguesa foi desenvolvida e mostrou-se uma ferramenta útil para estimar desempenho cognitivo.

Palavras-chave: Testes neuropsicológicos, inteligência, idosos.

When cognitive decline is suspected, a previous neuropsychological assessment that could serve as a criterion for comparison is rarely available. Thus, one of the great challenges faced in this field is the attempt to estimate premorbid

\footnotetext{
'Universidade de São Paulo, Faculdade de Medicina, Departamento de Clínica Médica, Disciplina de Geriatria, São Paulo SP, Brasil; ${ }^{2}$ Hospital das Clínicas, Divisão de Psicologia, São Paulo SP, Brasil;

${ }^{3}$ Universidade de São Paulo, Faculdade de Medicina, Departamento de Neurologia, Grupo de Neurologia Cognitiva e Comportamental, São Paulo SP, Brasil; «Universidade de São Paulo, Escola de Artes, Ciências e Humanidades, São Paulo SP, Brasil.

Gislaine Gil (iD https://orcid.org/0000-0002-0375-0910; Regina Miksinan Magaldi iD https://orcid.org/0000-0001-9104-2406; Alexandre Leopold Busse (iD) https://orcid.org/0000-0002-6709-2216; Elyse Soares Ribeiro iD https://orcid.org/0000-0003-4732-2464; Sonia Maria Dozzi Brucki iD https://orcid.org/0000-0002-8303-6732; Mônica Sanches Yassuda iD https://orcid.org/0000-0002-9182-2450; Wilson Jacob-Filho iD
} https://orcid.org/0000-0003-2290-4492

Correspondence: Daniel Apolinario; Departamento de Clínica Médica, Disciplina de Geriatria, / FMUSP;Av. Dr. Enéas de Carvalho Aguiar, 155 / 80 Andar / Bloco 3 ; 05403-900 São Paulo SP, Brasil; E-mail: daniel.apolinario@usp.br

Conflict of interest: There is no conflict of interest to declare.

Received 20 December 2018; Received in final form 18 March 2019; Accepted 24 April 2019. 
intelligence, a benchmark against which current neuropsychological functioning is compared in order to establish the existence and degree of cognitive decline ${ }^{1}$.

Reading tests comprising irregularly-spelled words are highly correlated with cognitive performance and have proven to be useful in estimating premorbid intelligence ${ }^{2}$. Those tests can be used for adjusting norms, thus helping clinicians to detect cognitive decline by comparing the actual performance with the performance that would be expected ${ }^{3}$. Pronunciation of irregular words must be accessed from a lexical store and not by grapheme-phoneme correspondence rules. Lexical functions that rely on implicit memory are less dependent on higher cognitive processes and, therefore, are relatively stable in normal aging and neuropathological conditions ${ }^{4}$. Accordingly, it has been shown that patients with dementia can read irregular words even when their meaning can no longer be assessed ${ }^{5}$.

The first well-structured reading test designed to estimate premorbid intelligence was the National Adult Reading Test (NART), which requires participants to read aloud a list of 50 words with irregular spelling-sound correspondence ${ }^{6}$. The NART, originally developed in England, has been adapted for North American and Canadian English speakers ${ }^{7}$. Versions of the NART have also been successfully validated in other languages such as Italian, French, Japanese, Korean, and Polish ${ }^{8,9,10,11,12}$.

Some languages, such as Swedish, Spanish, and Portuguese, are orthographically transparent, meaning that there is almost total correspondence between graphemes and phonemes. In these languages, versions of the NART seem unattainable, because most readers can pronounce previously-unknown words by using phoneme-grapheme correspondence rules. Therefore, in countries with transparent languages, alternative strategies have been designed to create irregularity between grapheme and phoneme $\mathrm{e}^{13,14}$.

Del Ser et al. ${ }^{15}$ designed the Word Accentuation Test (WAT) by using a newly-proposed source of irregularity between grapheme and phoneme. In Spanish, accent marks are an extra symbol added to existing letters to indicate the stressed syllable. However, when the accent mark is not present, the Spanish readers need to have prior knowledge to achieve a correct pronunciation. Using that rationale, the WAT requests participants to read aloud a list of words without the accent marks. The WAT has been demonstrated to have adequate properties in Spain, Argentina, Colombia, and among Spanishspeaking immigrants in the United States ${ }^{15,16,17,18}$.

Brazil is a country with 208 million inhabitants in which Portuguese is the only language in daily life ${ }^{19}$. No validated test is available to assess premorbid intelligence in Brazil. Because Portuguese is also a transparent language and its pronunciation is strongly based on accent marks, our aim was to develop a version of the WAT for Portuguese speakers.

In this study, an initial pool of 60 items was selected and a final version of 40 items (named the WAT-Br) was derived by item response theory. Initial validation criteria were obtained by assessing item discrimination, item difficulty, and correlation with neuropsychological tests. In addition, we calculated the internal consistency and assessed the inter-rater reliability of the proposed test.

\section{METHODS}

\section{Elaborating the preliminary version of the test}

A preliminary study was conducted to establish an initial list of words that were suited for composing the test. The first step consisted of selecting 300 words with graphic accents from Brazilian Portuguese dictionaries. We did not include: 1) words with more than one possible pronunciation (e.g., "equilátero"); 2) words in which the absence of a graphic accent indicates a different meaning or grammatical class (e.g., "denúncia" vs "denuncia"); 3) words borrowed from other languages (foreignisms); 4) technical jargon; and 5) words with a regional bias determining variation of frequency across the country, such as those representing fauna, flora, cuisine, artistic expressions, or proper names.

Subsequently, three of the authors reviewed the initial pool, through an iterative process and successive discussions, to select 60 words. Because difficulty of pronunciation is influenced by word occurrence, we selected words with a variety of frequencies in the Brazilian corpus: 19 with high frequency (> 1/1,000), 26 with intermediate frequency (between $1 / 1,000$ and $1 / 10,000)$, and 15 with low frequency $(<1 / 10,000)^{20}$. The selection was conducted with the additional goal of ensuring the same proportion of words stressed in the last, penultimate, and antepenultimate syllable (20/20/20).

\section{Participants}

We recruited 206 healthy community-dwelling individuals aged 60 years and older from different regions of the city of São Paulo, in southeast Brazil. Recruitment was targeted to obtain a minimum of 30 participants in each preplanned age and schooling strata, as shown in Table 1. The sample size was calculated to suffice for a two-parameter logistic model with a dichotomously-scored test, in which at least 200 respondents are recommended for accurate parameter estimates ${ }^{21}$.

General exclusion criteria were: suspected cognitive impairment (consistent self-complaint or cognitive decline reported by a close informant), diagnosis of neurological diseases, psychiatric disorders, use of medications with deleterious effects on the central nervous system, severe or decompensated clinical condition, and severe sensory deficit (visual or auditory). Non-native speakers were allowed to participate as long as they had been living in Brazil for at least 10 years and were perfectly fluent in Portuguese.

Three tests were performed for screening major exclusion criteria. Individuals were excluded if they presented with cognitive impairment indicated by a delayed recall $<7$ on the Brief Cognitive Screening Battery ${ }^{22}$, functional 
impairment as indicated by a score $>5$ on the Functional Activities Questionnaire ${ }^{23}$ or fulfilled criteria for major depressive disorder as defined by the Patient Health Questionnaire- $9^{24}$. The study was approved by the institutional review board. All the participants signed an informed consent before the research interview.

\section{Assessment}

The respondents received the initial list of 60 words in a descending order of frequency observed in the Brazilian corpus. The items were printed on an A4 sheet, (Times New Roman, font size 20). The test was presented to the examinee as follows: Please, read aloud, slowly, the following words. You may not recognize some words, but try reading them anyway. Examiners scored whether or not the participants pronounced the words correctly and one point was assigned for each correctly read word. Individuals who declared being unable to read even simple words were considered to have a score of zero. The list of words, administration instructions, and scoring rules are available in the Appendix.

For assessing inter-rater reliability, ratings were performed by two observers in 58 random participants. In this subsample, a resident physician remained in the testing room to record the score of the WAT-Br independently.

All participants underwent a 60-minute standardized neuropsychological battery for evaluating memory (Hopkins Verbal Learning Test-Revised ${ }^{25}$ and the Logical Memory Test of the Wechsler Memory Scale ${ }^{26}$ ), attention (Forward and Backward Digit Span of the Wechsler Adult Intelligence Scale-III ${ }^{27}$ and Color Trails $1^{28}$ ), language (Semantic Fluency for Animals ${ }^{29}$ and 30-item version Boston Naming Test $^{30}$ ), visuospatial functions (Line Orientation of the Repeatable Battery for the Assessment of Neuropsychological Status ${ }^{31}$ and CLOX $1^{32}$ ), and executive functions (Color Trails $2^{28}$ and Matrix Reasoning of the Wechsler Abbreviated Scale of Intelligence ${ }^{33}$ ). A global composite score was derived by averaging z-scores of the primary measures described above.

\section{Statistical analysis}

First, we conducted an exploratory factor analysis to test unidimensionality. A principal component analysis was undertaken based on a tetrachoric correlation matrix. A scree plot of the eigenvalues was derived for visual inspection and the number of factors to be retained was guided by Horn's parallel analysis with 100 randomly generated datasets ${ }^{34}$.

A two-parameter logistic item response theory model was fitted to provide information regarding discrimination $(\alpha)$ and difficulty $(\beta)$. Items with discrimination values $(\alpha)$ ranging from 0 to 0.64 show poor discrimination, 0.65 to 1.34 moderate discrimination, 1.35 to 1.69 high discrimination, and above 1.70 very high discrimination ${ }^{35}$. Item difficulty values $(\beta)$ typically range between -2 and +2 , with higher values indicating a greater amount of latent trait needed to obtain a correct pronunciation.
The initial pool of items was reduced using a strategy that would maximize psychometric properties and efficiency by selecting items with high discrimination and that were targeted to span a wide range of difficulty levels. To reduce possible redundancy, we eliminated items that were measuring the same level of difficulty.

Internal consistency was assessed using the KuderRichardson formula 20 (KR-20), with values above 0.70 indicating satisfactory internal consistency ${ }^{36}$. The intraclass correlation coefficient (ICC) was used to assess inter-rater reliability. The ICC was calculated using a one-way random-effects model for absolute agreement. Values between 0.75 and 0.90 were taken as indicative of good inter-rater agreement and those greater than 0.90 indicated excellent agreement ${ }^{37}$.

Because formal education has been widely used for adjusting norms on neuropsychological tests, we investigated whether the WAT-Br would provide independent predictive power in addition to schooling for predicting cognitive performance. Fractional polynomial regression models were used to account for the nonlinear relationship between predictors and cognitive performance. Nonlinear terms were fitted if they explained variability in the cognitive scores significantly better than a simple linear pattern. The adjusted coefficients of determination of the regression models were used to estimate the proportion of the variance on cognitive performance that could be predicted by the WAT-Br and schooling. The Wald test was used in a hierarchical strategy to test significance of the additional predictor.

All statistical analyses were performed using Stata for Windows, version 14.1 (StataCorp, College Station, TX). The level of statistical significance was set at.05 in two-tailed tests.

\section{RESULTS}

Our sample consisted of 206 cognitively unimpaired Brazilians with ages varying from 60 to 98 years (mean 73.6 years; $\mathrm{SD}=7.6$ ), representing several levels of formal education (mean 8.0 years; $\mathrm{SD}=5.2$ ). Fifteen participants $(7.3 \%)$ were born in other countries. The immigrants had similar schooling (7.4 vs 8.0; $\mathrm{p}=0.666$ ) and a similar performance on the WAT-Br (23.3 vs 23.2; $\mathrm{p}=0.968$ ) when compared with native speakers. The characteristics of the sample are shown in Table 1.

The first factor of the 60-item principal component analysis showed an eigenvalue of 32.4 and explained $53.9 \%$ of the variance. The second component was substantially smaller, accounting for only $3.4 \%$ of the variance. Only the first eigenvalue was greater than the corresponding average in parallel analysis, thus confirming the one-factor structure.

Only one item was excluded for showing poor discrimination ("solideu"; $\alpha=0.63$ ). Significant redundancy was detected for items with difficulty $(\beta)$ between -1 and 0 . Therefore, the 19 items with the lowest discrimination parameters in this difficulty level were eliminated. 
Table 1.Characteristics of the study sample $(n=206)$.

\begin{tabular}{|c|c|c|c|c|}
\hline Variable & Category & $\mathrm{N}(\%)$ & WAT-Br ${ }^{*}$ & $p$-value ${ }^{* *}$ \\
\hline \multirow{3}{*}{ Age } & $60-69$ years & 74 (35.9) & $23.7(9.7)$ & \multirow{3}{*}{0.2026} \\
\hline & $70-79$ years & $92(44.7)$ & $24.0(9.1)$ & \\
\hline & $\geq 80$ years & $40(19.4)$ & $20.9(10.0)$ & \\
\hline \multirow{2}{*}{ Sex } & Female & 151 (73.3) & $22.9(10.0)$ & \multirow{2}{*}{0.4050} \\
\hline & Male & 55 (26.7) & $24.1(10.9)$ & \\
\hline \multirow{4}{*}{ Schooling } & $0-3$ years & $34(16.5)$ & $10.0(7.6)$ & \multirow{4}{*}{$<0.001^{\star \star}$} \\
\hline & 4-7 years & $66(32.0)$ & $20.4(5.4)$ & \\
\hline & $8-11$ years & $55(26.7)$ & $27.7(6.7)$ & \\
\hline & $\geq 12$ years & $51(24.8)$ & $30.9(5.7)$ & \\
\hline \multirow{4}{*}{$\begin{array}{l}\text { Color or } \\
\text { ethnicity }\end{array}$} & White & $122(59.2)$ & $24.2(9.4)$ & \multirow{4}{*}{$<0.001^{* \star \star}$} \\
\hline & Admixed & $30(15.0)$ & $18.3(10.2)$ & \\
\hline & Black & $15(7.3)$ & $18.5(7.8)$ & \\
\hline & Asians & $38(18.4)$ & $26.3(7.7)$ & \\
\hline
\end{tabular}

*The final version of the Brazilian version of the Word Accentuation Test (WAT-Br) is presented as means (standard deviation) for each demographic stratum; $* *$ Post hoc analysis with the Scheffe method revealed a $p$-value $<0.05$ for all comparisons; ***Post hoc analysis revealed significant differences between Admixed vs White and between Admixed vs Asians.

The final scale, the WAT-Br, comprised 40 words: 12 with the stress on the last syllable, 13 with stress on the penultimate, and 15 with the stress on the antepenultimate syllable. Items showed moderate-to-high discrimination ( $\alpha$ ranging from 0.93 to 25.04) and spanned a wide range of difficulty ( $\beta$ between -2.07 and 1.40; Table 2).

Overall KR-20 for the 40 items was 0.95 , indicating high internal consistency. The ICC between two independent raters was 0.92 (95\%CI 0.86 to 0.95 ), indicating excellent interrater agreement.

Scores of the WAT-Br varied from 0 to 40 , with a mean of $23.2( \pm 9.5)$. We observed a normal distribution and only $1.4 \%$ of the sample obtained the maximum score, suggesting that the ceiling effect was not a significant problem. The WAT-Br scores did not vary across age and sex strata, but were significantly associated with education and race (Table 1). When adjusted for education, differences between races did not maintain significance and, in a stepwise backward model, the only demographic characteristic associated with the WAT-Br scores was education $(\beta=1.34$; $p<0.001)$

A linear relationship was found between the WAT-Br and the global composite score of the neuropsychological battery (Figure), with a Pearson's correlation coefficient of 0.78 and a coefficient of determination $\left(\mathrm{R}^{2}\right)$ of 0.61 , which means that the WAT-Br predicted $61 \%$ of the variance in global cognitive performance.

In comparison with schooling, the WAT-Br provided equal or superior prediction of cognitive performance for all neuropsychological scores (Table 3). The addition of the schooling to a model already containing the WAT-Br improved the explained variance modestly for a few neuropsychological measures. On the other hand, the prediction of all neuropsychological measures was significantly improved by adding the WAT-Br to models already containing schooling.
Table 2. Final version of the Brazilian Word Accentuation Test (WAT-Br) with parameter estimates for a two-parameter logistic model.

\begin{tabular}{|c|c|c|c|}
\hline Accented Form & WAT-Br Item & Difficulty $(\beta)$ & Discrimination $(\alpha)$ \\
\hline você & voce & -2.072 & 4.555 \\
\hline política & politica & -1.963 & 25.04 \\
\hline café & cafe & -1.962 & 4.732 \\
\hline açúcar & açucar & -1.909 & 4.205 \\
\hline herói & heroi & -1.668 & 3.989 \\
\hline após & apos & -1.562 & 2.231 \\
\hline alguém & alguem & -1.532 & 4.582 \\
\hline táxi & taxi & -1.338 & 3.649 \\
\hline pôster & poster & -1.277 & 1.360 \\
\hline dossiê & dossie & -1.090 & 2.407 \\
\hline canapé & canape & -1.040 & 2.748 \\
\hline flexível & flexivel & -1.022 & 4.660 \\
\hline aprazivel & aprazivel & -0.963 & 3.307 \\
\hline talismã & talisma & -0.866 & 2.335 \\
\hline igarapé & igarape & -0.804 & 2.510 \\
\hline dócil & docil & -0.579 & 2.930 \\
\hline convés & conves & -0.442 & 3.271 \\
\hline mártir & martir & -0.410 & 3.356 \\
\hline cântaro & cantaro & -0.348 & 2.712 \\
\hline eloquência & eloquencia & -0.330 & 3.231 \\
\hline síncope & sincope & -0.234 & 4.141 \\
\hline munícipe & municipe & 0.018 & 3.291 \\
\hline lúgubre & lugubre & 0.254 & 2.242 \\
\hline léxico & lexico & 0.273 & 3.054 \\
\hline amálgama & amalgama & 0.324 & 2.732 \\
\hline melífluo & melifluo & 0.376 & 1.358 \\
\hline lânguido & languido & 0.430 & 2.358 \\
\hline atávico & atavico & 0.462 & 1.663 \\
\hline uníssono & unissono & 0.462 & 3.288 \\
\hline marzipã & marzipa & 0.582 & 2.097 \\
\hline antiquíssimo & antiquissimo & 0.595 & 1.360 \\
\hline oboé & oboe & 0.657 & 1.098 \\
\hline exegético & exegetico & 0.684 & 0.931 \\
\hline antítese & antitese & 0.776 & 2.218 \\
\hline córtex & cortex & 0.845 & 2.396 \\
\hline látex & latex & 0.853 & 1.186 \\
\hline aquífero & aquifero & 0.862 & 2.566 \\
\hline arquétipo & arquetipo & 0.955 & 3.500 \\
\hline exequível & exequivel & 1.279 & 1.723 \\
\hline hálux & halux & 1.404 & 1.113 \\
\hline
\end{tabular}

WAT-Br: Brazilian Word Accentuation Test.

\section{DISCUSSION}

In this report we present the development of the Brazilian Word Accentuation Test (WAT-Br) and provide a preliminary investigation of its psychometric properties. From an initial poll of 60 items, we derived a final version with 40 items that was evaluated.

The WAT-Br showed high internal consistency $(\mathrm{KR}-20=0.95)$. This finding is in line with the versions of the WAT for Spanish-speaking populations that showed values varying from 0.91 to $0.95^{15-17}$. In addition, an excellent 


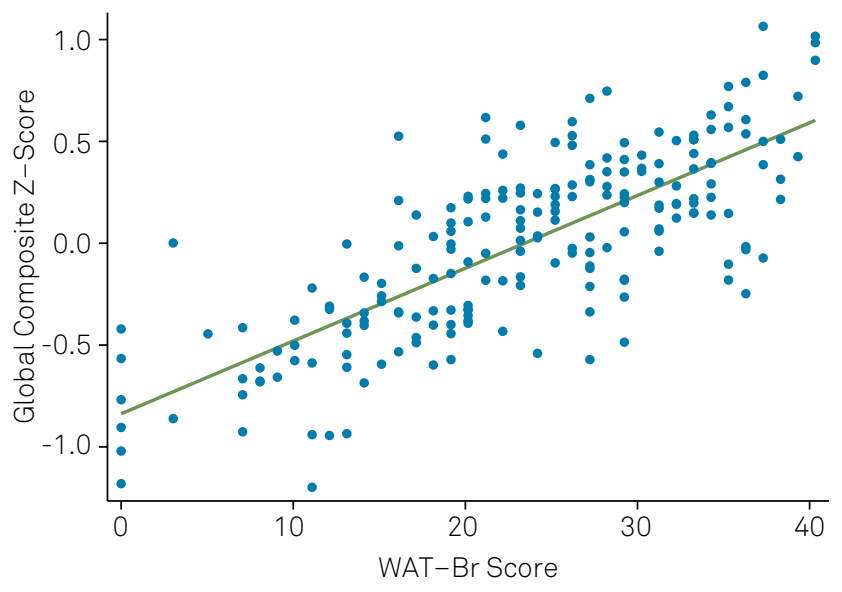

Figure. Scatter plot showing a linear relationship between the WAT-Br and the global composite z-score.

inter-rater agreement was found in our study (ICC $=0.92)$, aligned with the value found in Spain (ICC $=0.93$ ) by Del Ser et al. ${ }^{15}$ Finally, the WAT-Br accounted for $61 \%$ of the variance observed in the global composite score for current cognitive performance, a value that is in the range of those found by studies that used the WAT to predict the WAIS full-scale IQ in Spanish-speaking samples ${ }^{17}$.

This is the first study to show that the ability of reading Portuguese words without accent marks is a good indicator of lexical knowledge and that this task may be an efficient way of estimating cognitive performance in Portuguesespeaking adults. This finding is of paramount importance for most Portuguese-speaking countries, where social inequality remains a relevant problem. In those countries, with heterogeneous quality of education, schooling may not be the best indicator of premorbid cognitive performance.

Our study included a heterogeneous sample. A significant proportion of the participants (40.8\%) were not white and a wide range of schooling levels were represented. Nineteen unschooled individuals were included and $68.4 \%$ of them were able to read at least one word, thus revealing that the WAT-Br can discriminate performance even in populations with very low levels of schooling or no schooling at all. We also included individuals born in other countries. Brazil received many European and Japanese immigrants during World War II. Therefore, the inclusion of non-native speakers was important to improve the external validity of the study.

An irregular word reading test, the TeLPI, was developed in Portugal using the very few grapheme-phoneme irregularities encountered in Portuguese ${ }^{13}$, namely the pronunciation of the intervocalic " $x$ " or the syllables "que/qui/gue/gui", that can have more than one pronunciation ${ }^{38}$. The TeLPI was able to predict only $53 \%$ of the variance of the WAIS full-scale $\mathrm{IQ}^{14}$. In contrast, in Spanish-speaking populations, the WAT predicted between $59 \%$ and $70 \%$ of the variance in the WAIS full-scale IQ scores ${ }^{15,17}$. These findings suggest that exploring the few grapheme-phoneme irregularities encountered in Portuguese may be a limited strategy. Future studies using the WAT to predict the WAIS full-scale IQ in Portuguesespeaking populations will provide more adequate parameters of comparison between these two assessment strategies.

Although the focus of our test was the ability to read words without the accent marks, items with additional elements of irregularity were not excluded. Indeed, 10 of the 40 words of the final list contained an intervocalic " $\mathrm{x}$ " or the syllables "que/qui/gue/gui". Therefore, the WAT-Br is not a pure test in its linguistic mechanism of irregularity. As can be seen in Table 2, words with additional irregularities are among the most difficult and were important to avoid a ceiling effect. A concern could be raised about the presence of more than one irregularity mechanism increasing the variance. However, that concern was not confirmed, once the test showed an excellent internal consistency.

Table 3. Hierarchical strategy to test significance of adding the WAT-Br to a model already containing schooling.

\begin{tabular}{|c|c|c|c|c|}
\hline \multirow{2}{*}{ Variable } & \multicolumn{3}{|c|}{ Coefficient of Determination $\left(\mathrm{R}^{2}\right)$} & \multirow{2}{*}{ Change in $\mathrm{R}^{2 \star}$} \\
\hline & Schooling & WAT-Br & Schooling + WAT-Br & \\
\hline HVLT-R total recall & 0.20 & 0.25 & 0.25 & 0.05 \\
\hline HVLT-R delayed recall & 0.18 & 0.25 & 0.25 & 0.07 \\
\hline WMS-III logical memory I & 0.21 & 0.21 & 0.24 & 0.03 \\
\hline WMS-III logical memory II & 1,058 & 0.27 & 0.28 & 0.06 \\
\hline WAIS-III digit span & 0.24 & 0.37 & 0.36 & 0.12 \\
\hline Color trails test 1 & 0.54 & 0.68 & 0.70 & 0.16 \\
\hline Color trails test 2 & 0.51 & 0.64 & 0.64 & 0.13 \\
\hline Verbal fluency (animals) & 0.14 & 0.21 & 0.21 & 0.07 \\
\hline Boston naming test & 0.52 & 0.70 & 0.70 & 0.18 \\
\hline Clock drawing test (CLOX1) & 0.36 & 0.43 & 0.43 & 0.07 \\
\hline RBANS line orientation & 0.35 & 0.45 & 0.46 & 0.11 \\
\hline WASI matrix reasoning & 0.42 & 0.49 & 0.53 & 0.11 \\
\hline Global composite score & 0.47 & 0.61 & 0.62 & 0.15 \\
\hline
\end{tabular}

*The Wald test been used in a hierarchical strategy to test significance of adding the WAT-Br (Brazilian Word Accentuation Test) to a model already containing schooling. The prediction of all neuropsychological measures was significantly improved by adding the WAT- $\operatorname{Br}$ (all with $p<0.01$ ). HVLT-R: Hopkins Verbal Learning Test-Revised; WMS: Wechsler Memory Scale; WAIS-III: Wechsler Adult Intelligence Scale; RBANS: Repeatable Battery for the Assessment of Neuropsychological Status; WASI: Wechsler Abbreviated Scale of Intelligence. 
This research has some limitations that should be noted. Firstly, although a sample with 206 participants was deemed sufficient for a two-parameter logistic model, a larger sample would have provided more accurate parameter estimates. Secondly, although the sample was diverse and represented a wide range of schooling levels, this was a single-center study. Further research with samples from different regions of the country is needed to validate our findings. Thirdly, only a few items had a difficulty parameter $(\beta)$ above 1 , raising the concern that the WAT-Br may be a limited tool for estimating cognitive performance in persons with high levels of the latent trait. In this study, we found a linear relationship between the WAT-Br and cognitive performance without a plateau at higher levels. However, because the ceiling effect has been a common phenomenon among tests of irregular words, this concern should be examined in highly-educated individuals.

In conclusion, a version of the WAT for Portuguesespeaking populations has been developed and proved to be a valid tool for estimating cognitive performance. Future studies should evaluate the WAT-Br as a predictor of intelligence and evaluate its stability in patients with cognitive impairment.

\section{References}

1. Lezak MD, Howieson DB, Bigler ED, Tranel D. Neuropsychological Assessment. 5th ed. New York: Oxford University Press; 2012.

2. Nelson HE, McKenna P. The use of current reading ability in the assessment of dementia. Br J Soc Clin Psychol. 1975 Sep;14(3):259-67. https://doi.org/10.1111/j.2044-8260.1975.tb00178.x

3. Del Pino R, Peña J, Ibarretxe-Bilbao N, Schretlen DJ, Ojeda N. Demographically Calibrated Norms for Two Premorbid Intelligence Measures: The Word Accentuation Test and Pseudo-Words Reading Subtest. Front Psychol. 2018 Oct;9:1950. https://doi.org/10.3389/fpsyg.2018.01950

4. Bayles KA, Boone DR. The potential of language tasks for identifying senile dementia.J Speech Hear Disord. 1982 May;47(2):210-7. https://doi.org/10.1044/jshd.4702.210

5. McGurn B, Starr JM, Topfer JA, Pattie A, Whiteman MC, Lemmon HA, et al. Pronunciation of irregular words is preserved in dementia, validating premorbid IQ estimation. Neurology. 2004 Apr;62(7):1184-6. https://doi.org/10.1212/01.WNL.0000103169.80910.8B

6. Nelson HE, O'Connell A. Dementia: the estimation of premorbid intelligence levels using the New Adult Reading Test. Cortex. 1978 Jun;14(2):234-44. https://doi.org/10.1016/S0010-9452(78)80049-5

7. Blair JR, Spreen O. Predicting premorbid IQ: A revision of the national adult reading test. Clin Neuropsychol. 1989;3(2):129-36. https://doi.org/10.1080/13854048908403285

8. Colombo L, Brivio C, Benaglio I, Siri S, Capp SF. Alzheimer patients' ability to read words with irregular stress. Cortex. 2000 Dec;36(5):703-14. https://doi.org/10.1016/S0010-9452(08)70547-1

9. Mackinnon A, Mulligan R. [The estimation of premorbid intelligence levels in French speakers]. Encephale. 2005 Jan-Feb;31(1 Pt 1):31-43. French. https://doi.org/10.1016/S0013-7006(05)82370-X

10. Matsuoka K, Uno M, Kasai K, Koyama K, Kim Y. Estimation of premorbid IQ in individuals with Alzheimer's disease using Japanese ideographic script (Kanji) compound words: Japanese version of National Adult Reading Test. Psychiatry Clin Neurosci. 2006 Jun;60(3):332-9. https://doi.org/10.1111/j.1440-1819.2006.01510.x

11. Yi D, Seo EH, Han JY, Sohn BK, Byun MS, Lee $\mathrm{JH}$, et al. Development of the Korean Adult Reading Test (KART) to estimate premorbid intelligence in dementia patients. PLoS One. 2017 Jul;12(7):e0181523. https://doi.org/10.1371/journal.pone.0181523

12. Karakuła-Juchnowicz H, Stecka M. [Polish Adult Reading Test (PART) - construction of Polish test for estimating the level of premorbid intelligence in schizophrenia]. Psychiatr Pol. 2017 Aug;51(4):673-85. Polsky. https://doi.org/10.12740/PP/OnlineFirst/63207

13. Rolstad S, Nordlund A, Gustavsson MH, Eckerström C, Klang O, Hansen S, et al. The Swedish National Adult Reading Test (NART-SWE): a test of premorbid IQ. Scand J Psychol. 2008 Dec;49(6):577-82. https://doi.org/10.1111/j.1467-9450.2008.00677.x

14. Alves L, Simões MR, Martins C. The estimation of premorbid intelligence levels among Portuguese speakers: the Irregular Word Reading Test (TeLPI). Arch Clin Neuropsychol. 2012 Jan;27(1):58-68. https://doi.org/10.1093/arclin/acr103

15. Del Ser T, González-Montalvo JI, Martínez-Espinosa S, Delgado-Villapalos C, Bermejo F. Estimation of premorbid intelligence in Spanish people with the Word Accentuation Test and its application to the diagnosis of dementia. Brain Cogn. 1997 Apr;33(3):343-56. https://doi.org/10.1006/brcg.1997.0877

16. Burin DI, Jorge RE, Arizaga RA, Paulsen JS. Estimation of premorbid intelligence: the word accentuation test: Buenos Aires version. J Clin Exp Neuropsychol. 2000 Oct;22(5):677-85. https://doi.org/10.1076/1380-3395(200010)22:5;1-9;FT677

17. Sierra Sanjurjo N, Montañes P, Sierra Matamoros FA, Burin D. Estimating intelligence in Spanish: regression equations with the word accentuation test and demographic variables in Latin America. Appl Neuropsychol Adult. 2015;22(4):252-61. https://doi.org/10.1080/23279095.2014.918543

18. Schrauf RW, Weintraub S, Navarro E. Is adaptation of the word accentuation test of premorbid intelligence necessary for use among older, Spanish-speaking immigrants in the United States? J Int Neuropsychol Soc. 2006 May;12(3):391-9. https://doi.org/10.1017/S1355617706060462

19. Instituto Brasileiro de Geografia e Estatística - IBGE. Projeção da população do Brasil e das Unidades de Federação. 2018 [cited 2018 Dec 20]. Available from: https://www.ibge.gov.br/apps/populacao/projecao

20. Sardinha TB, Moreira Filho JL, Alambert E. Manual do corpus brasileiro. [cited 2018 Dec 20]. Available from: https://www.linguateca.pt/Repositorio/manual_cb.pdf

21. Thorpe GL, Andrej F. Data analysis using item response theory methodology: an introduction to selected programs and applications. Psychol Faculty Scholarship. 2012 [cited 2018 Dec 20]. Available from: https://digitalcommons.library.umaine.edu/psy_facp

22. Nitrini R, Lefèvre BH, Mathias SC, Caramelli P, Carrilho PE, Sauaia $\mathrm{N}$, et al. [Neuropsychological tests of simple application for diagnosing dementia]. Arq Neuropsiquiatr. 1994 Dec;52(4):457-65. Portuguese. https://doi.org/10.1590/S0004-282X1994000400001 
23. Pfeffer RI, Kurosaki TT, Harrah $\mathrm{CH} J$ r, Chance JM, Filos S. Measurement of functional activities in older adults in the community. J Gerontol. 1982 May;37(3):323-9. https://doi.org/10.1093/geronj/37.3.323

24. Kroenke K, Spitzer RL, Williams JB. The PHQ-9: validity of a brief depression severity measure. J Gen Intern Med. 2001 Sep;16(9):606-13. https://doi.org/10.1046/j.1525-1497.2001.016009606.x

25. Shapiro AM, Benedict RH, Schretlen D, Brandt J. Construct and concurrent validity of the Hopkins Verbal Learning Test-revised. Clin Neuropsychol. 1999 Aug;13(3):348-58. https://doi.org/10.1076/clin.13.3.348.1749

26. Woodard JL, Axelrod BN. Parsimonious prediction of Wechsler Memory Scale: revised memory indices. Psychol Assess. 1987;7(4):445-9. http://dx.doi.org/10.1037/1040-3590.7.4.445

27. Wechsler D. WAIS--III administration and scoring manual. San Antonio (TX): The Psychological Corporation; 1997.

28. Williams J, Rickert v, Hogan J, Zolten AJ, Satz P, D’Elia F, et al. Childrens color trails. Arch Clin Neuropsychol. 1995 May-Jun;10(3):211-23. https://doi.org/10.1016/0887-6177(94)00041-N

29. Rosen W. Verbal fluency in aging and dementia.J Clin Neuropsychol. 1980;2(2):135-46. https://doi.org/10.1080/01688638008403788

30. Park LQ, Gross AL, McLaren DG, Pa J, Johnson JK, Mitchell $M$, et al.; Alzheimer's Disease Neuroimaging Initiative. Confirmatory factor analysis of the ADNI Neuropsychological Battery. Brain Imaging Behav. 2012 Dec;6(4):528-39. https://doi.org/10.1007/s11682-012-9190-3
31. Randolph C, Tierney MC, Mohr E, Chase TN. The Repeatable Battery for the Assessment of Neuropsychological Status (RBANS): preliminary clinical validity.J Clin Exp Neuropsychol. 1998 Jun;20(3):310-9. https://doi.org/10.1076/jcen.20.3.310.823

32. Royall DR, Cordes JA, Polk M. CLOX: an executive clock drawing task. J Neurol Neurosurg Psychiatry. 1998 May;64(5):588-94. https://doi.org/10.1136/jnnp.64.5.588

33. Ryan JJ, Carruthers CA, Miller LJ, Souheaver GT, Gontkovsky ST, Zehr MD. The WASI matrix reasoning subtest: performance in traumatic brain injury, stroke, and dementia. Int J Neurosci. 2005 Jan;115(1):129-36. https://doi.org/10.1080/00207450490512704

34. Horn JL. A rationale and test for the number of factors in factor analysis. Psychometrika. 1965 Jun;30(2):179-85. https://doi.org/10.1007/BF02289447

35. Baker FB. The basics of item response theory. 2nd ed. Wisconsin: ERIC Clearinghouse on Assessment and Evaluation; 2001.

36. Kuder GF, Richardson MW. The theory of the estimation of test reliability. Psychometrika. 1937;2(3):151-60. https://doi.org/10.1007/BF02288391

37. Koo TK, Li MY. A Guideline of Selecting and Reporting Intraclass Correlation Coefficients for Reliability Research.J Chiropr Med. 2016 Jun;15(2):155-63. https://doi.org/10.1016/j.jcm.2016.02.012

38. Alves L, Martins C. Simões MR. Premorbid Intelligence Evaluation: development of the experimental version of the Irregular Words Reading Test (TeLPI) for Portuguese Population. Psychologia. 2010;53:299-312. https://doi.org/10.14195/1647-8606_53_14

\section{APPENDIX}

Brazilian Version of the Word Accentuation Test (WAT-Br)

\begin{tabular}{|lll|}
\hline 1. VOCE & 15. IGARAPE & 29. ATAVICO \\
\hline 2. CAFE & 16. DOCIL & 30. MARZIPA \\
\hline 3. ACUCAR & 17. CONVES & 31. ANTIQUISSIMO \\
\hline 4. POLITICA & 18. MARTIR & 32. OBOE \\
\hline 5. HEROI & 19. CANTARO & 33. EXEGETICO \\
\hline 6. APOS & 20. ELOQUENCIA & 34. ANTITESE \\
\hline 7. ALGUEM & 21. SINCOPE & 35. CORTEX \\
\hline 8. TAXI & 22. MUNICIPE & 36. AQUIFERO \\
9. POSTER & 23. LUGUBRE & 37. LATEX \\
10. DOSSIE & 24. LEXICO & 38. ARQUETIPO \\
11. CANAPE & 25. AMALGAMA & 39. EXEQUIVEL \\
12. FLEXIVEL & 26. MELIFLUO & 40. HALUX \\
\hline 13. TALISMA & 27. LANGUIDO & \\
\hline
\end{tabular}

\section{INSTRUÇÕES}

- "Agora eu quero que você leia essas palavras em voz alta. Não se preocupe com o significado das palavras. Apenas

\section{leia em voz alta."}

- "Comece por essa palavra (aponte), passe para a debaixo e assim por diante. Quando terminar essa coluna vá para a próxima coluna (aponte).”

\section{• "Leia sem pressa, uma palavra de cada vez."}

\section{REGRAS DE APLICACÃ̃O}

- Caso o sujeito comece a ler rápido interrompa e peça que leia mais devagar.

- Caso comece a ler em tom de voz baixo interrompa e peça que leia mais alto.

- Caso você não tenha ouvido bem alguma palavra, solicite que a palavra seja repetida. 
- Interrompa o teste após 10 erros sequenciais. É possível permitir que o indivíduo complete a tarefa mesmo após 10 erros sequenciais, desde que se perceba interesse na tentativa e não haja sinais de constrangimento. Não pontue eventuais pronúncias corretas após 10 erros sequenciais.

- No caso de desistências precipitadas, tente incentivar para que o indivíduo continue.

\section{REGRAS DE PONTUAÇÃO}

- Antes de administrar o teste familiarize-se com a pronúncia das palavras. Atente-se aos erros de sílabas tônicas (acentuação), pronúncia do "X" que pode ter som de "cs" ( flexível) ou " $z$ " (exequível) e pronúncia do "QU" que pode ter som de "k" (arquétipo) ou "qü" (eloquência).

- São aceitas pronúncias variantes por coloquialismo, sotaque ou dicção. No Nordeste é comum a palatização das consoantes "D" e "T", além da abertura das vogais pre-tônicas. No Rio de Janeiro utiliza-se o "S" palatal e o "R" aspirado. Em Minas Gerais as palavras podem ser encurtadas. Em muitas regiões do país permuta-se o som de "E" por "I" (munícipi) e "O" por "U" (léxicu) no final das palavras. Essas variações devem ser aceitas como corretas.

• No formulário de aplicação, circule "1" se a pronúncia for correta e "0" se a pronúncia for incorreta.

- Em caso de autocorreção considere a última tentativa.

- Um ponto é atribuído a cada palavra pronunciada corretamente (total de 0-40).

\begin{tabular}{|c|c|c|c|c|c|c|c|}
\hline 1. você & 0 & 1 & 15. igarapé & 0 & 1 & 29. atávico & 0 \\
\hline 2. café & 0 & 1 & 16. dócil & 0 & 1 & 30. marzipã & 0 \\
\hline 3. açúcar & 0 & 1 & 17. convés & 0 & 1 & 31. antiquíssimo [qü] & 0 \\
\hline 4. política & 0 & 1 & 18. mártir & 0 & 1 & 32. oboé & 0 \\
\hline 5. herói & 0 & 1 & 19. cântaro & 0 & 1 & 33. exegético [z] & 0 \\
\hline 6. após & 0 & 1 & 20. eloquência [qü] & 0 & 1 & 34. antítese & 0 \\
\hline 7. alguém [g] & 0 & 1 & 21. síncope & 0 & 1 & 35. córtex [cs] & 0 \\
\hline 8. táxi [cs] & 0 & 1 & 22. munícipe & 0 & 1 & 36. aquífero [qü] & 0 \\
\hline 9. pôster & 0 & 1 & 23. lúgubre & 0 & 1 & 37. látex [cs] & 0 \\
\hline 10. dossiê & 0 & 1 & 24. léxico [cs] & 0 & 1 & 38. arquétipo [k] & 0 \\
\hline 11. canapé & 0 & 1 & 25. amálgama & 0 & 1 & 39. exequível [z][qü] & 0 \\
\hline 12. flexível [cs] & 0 & 1 & 26. melífluo & 0 & 1 & 40. hálux [cs] & 0 \\
\hline 13. talismã & 0 & 1 & 27. lânguido [g] & 0 & 1 & & \\
\hline 14. aprazível & 0 & 1 & 28. uníssono & 0 & 1 & & TOTAL: \\
\hline
\end{tabular}

